\title{
Drug Trafficking and Youth Mortality in Brazil: An Expression of Human Rights' Violations*
}

\author{
Ana Paula Motta Costa* \\ Dani Rudinicki** \\ Julia Maia Goldani ${ }^{* \cdots *}$
}

Recibido: 12 de enero de 2017 • Aprobado: 17 de marzo de 2018

https://doi.org/10.22395/ojum.v17n34a1 1

\begin{abstract}
This paper aims to analyze the intersectional problematic that surrounds the violations of adolescents' human rights that happen in Brazil nowadays. It focuses, more specifically, on the involvement of these youths with drug trafficking, and on the relations between their participation in crime and the rising mortality rates amidst young age groups. A large part of Brazil's children and teenagers grow up in contexts of social vulnerability, lack of opportunities, difficult access to economical assets, and personal devaluation. This situation often pushes young individuals into involvement with drug trafficking or armed robbery, since crime represents, in their context, a possibility for economic and social ascendance. In parallel, the criminal policy adopted by the Brazilian State, synthesized in the expression "war on drugs" and manifested in the promulgation of Law 11.343/06, focuses on repressive police actions, and favors imprisonment, while doing nothing to attack the social causes of the problem. The result is the mass incarceration of young and economically disfavored individuals as well as, not infrequently, their deaths during police approaches, characterizing a situation where these adolescents are both perpetuators and victims of violence.
\end{abstract}

Keywords: Drug trafficking; youth criminality; adolescents; human rights; criminal policy.

This article is the result of research activities conducted by the signing professors in the area of Juvenile Justice and Human Rights, as a part of their activities in the Federal University of Rio Grande do Sul (UFRGS) and Centro Universitário Ritter dos Reis - Uniritter.

* Graduate in Law (PUC/RS) and Sociology (Unisinos), Master in Criminal Sciences (PUC/RS) and PhD in Law (PUC/RS). Professor in Criminal Law and Criminology at the Federal University of Rio Grande do Sul (UFRGS) and Centro Universitário Ritter dos Reis - Uniritter, teaching graduate and post-graduate courses in Criminology, Criminal Law, and Human Rights.

${ }^{* *}$ Graduate in Law (UFRGS) and Journalism (PUC/RS). Master in Law (Unisinos) and PhD in Sociology (UFRGS). Professor at Centro Universitário Ritter dos Reis - Uniritter, teaching graduate and postgraduate courses in Criminal Law and Sociology of Violence.

${ }^{* * *}$ Graduate student in Juridical and Social Sciences (Law) at the Federal University of Rio Grande do Sul (UFRGS), and research assistant to Prof. Ana Paula Motta Costa. 


\title{
Tráfico de estupefacientes y mortalidad juvenil en Brasil: una manifestación de violaciones de derechos humanos
}

\begin{abstract}
RESUMEN
Este artículo tiene como objetivo analizar la problemática intersectorial que atañe a las violaciones de los derechos humanos de los adolescentes que ocurren actualmente en Brasil. De modo específico, el estudio centra su atención en la participación de estos jóvenes en el tráfico de drogas, así como en las relaciones entre su participación en los crímenes y el aumento de las tasas de mortalidad en estos grupos etarios. Una gran parte de los niños y adolescentes de Brasil crece en contextos de vulnerabilidad social, falta de oportunidades, difícil acceso a bienes económicos y devaluación personal. Esta coyuntura suele llevar a los jóvenes a involucrarse en acciones de narcotráfico o robo a mano armada, ya que el crimen representa, en su contexto, una posibilidad de ascenso económico y social. De modo paralelo, la política penal adoptada por el Estado brasileño (sintetizada en la expresión "guerra contra las drogas" y manifestada en la promulgación de la Ley 11.34306) se centra en acciones policiales represivas y favorece el encarcelamiento, pero no se ocupa en atacar las causas sociales del problema. Lo anterior acarrea el encarcelamiento masivo - y, no en pocas ocasiones, la muerte- de personas jóvenes y desfavorecidas económicamente, con lo que se configura una situación en la que estos adolescentes son al mismo tiempo perpetuadores y víctimas de la violencia.
\end{abstract}

Palabras clave: tráfico de estupefacientes; delincuencia juvenil; adolescentes; derechos humanos; política penal.

\section{Tráfico de entorpecentes e mortalidade juvenil no Brasil: uma manifestação de violações de direito humanos}

\section{RESUMO}

Este artigo tem como objetivo analisar a problemática intersetorial que diz respeito às violações dos direitos humanos dos adolescentes que ocorrem atualmente no Brasil. De modo específico, o estudo centra sua atenção na participação desses jovens no tráfico de drogas, bem como nas relações entre sua participação nos crimes e o aumento das taxas de mortalidade nesses grupos etários. Uma grande parte das crianças e adolescentes do Brasil cresce em contextos de vulnerabilidade social, falta de oportunidades, difícil acesso a bens econômicos e desvalorização pessoal. Essa conjuntura costuma levar os jovens a envolver-se ações de narcotráfico ou roubo à mão armada, já que o crime representa, em seu contexto, uma possibilidade de ascensão econômica e social. Paralelamente, a política penal adotada pelo Estado brasileiro (sintetizada na expressão "guerra contra as drogas" e manifestada na promulgação da Lei 11.34306) se centra em ações policiais repressivas e favorece o encarceramento, mas não se ocupe em atacar as causas sociais do problema. Isso acarreta o encarceramento massivo - e, não em poucas ocasiões, a morte - de pessoas jovens e economicamente desfavorecidas, e assim configura-se uma situação na qual esses adolescentes são, ao mesmo tempo, perpetuadores e vítimas da violência.

Palavras-chave: tráfico de entorpecentes; delinquência juvenil; adolescentes; direitos humanos; política penal. 


\section{INTRODUCTION}

Two very specific realities come together to form the context of violence in which a significant quota of Brazilian adolescents is contemporaneously inserted: drug trafficking, and death by violent causes. Among adolescents serving socio-educative measures (destined by the Brazilian legal system to underage individuals who have committed penal infractions), $27,5 \%$ are doing so because of drug related charges (Secretaria Nacional de Promoção dos Direitos da Criança e do Adolescente, 2012). On the other hand, trafficking is one of the main factors related to youth mortality, in a context where the adolescents are both perpetuators and victims of the violence.

A rising tendency is observed regarding mortality rates, and young individuals seem to be more vulnerable to mortality by homicide, when compared to other age groups. The number of deaths per age begins to decrease only after the age of 20, where it becomes stable. Some of the data analyzed for this paper show that between 15 and 20 years of age, individuals have, at least, a threefold-enhanced chance of death caused by homicide than an adult does (Waiselfsz, 2016'). The risk is greater for subjects who are of male gender, have Negro or mixed racial origins, and live in peripheral zones of large metropolitan areas.

The challenge with which this study charges itself is to approach the referred inter-

Government study entitled "Map of Violence", published in 2016.s sectional context combining the methods of analyzing government-produced data and legislation, as well as bibliographical research, to answer a few prominent questions. How is it that a country such as Brazil, that has experienced a slow but significant process regarding amplification of state protection towards children and youths, has arrived in the 21st century with such grave violations of its adolescents' right to life? To what extent does the expansion of drug trafficking, and of the state's repressive criminal policies established in 2006 as a counter-measure, contribute to these violations? Why is death such a likely outcome for so many young Brazilians living in the periphery of large cities? And why has the State not been able to intervene, and assure their protection?

The answers to these inquiries are somewhat complicated. To begin with, it must be considered that deaths by fire weapons occur in contexts of easy access to guns. Such situations are common in the social and cultural reality of Brazilian urban peripheries, whose inhabitants are accustomed to the presence of guns in their daily routines. To die and to kill is a part of these individuals' universe, in which an indifference to life that goes unnoticed by the rest of society reigns, as do the majority of issues faced in these precarious urban areas. In this sense, poverty and exclusion from basic human rights also play an important role in the scenario.

Because of the complex nature of the issue, this qualitative study is essentially ex- 
ploratory. As mentioned, it is based on the techniques of bibliographical research, legislative analysis and interpretation of data presented in government reports.

Structured in four sections, this resulting paper aims in its first topic to contextualize the problematic by discussing the reality of urban violence that affects young individuals in Brazil. Next, it will present and analyze Brazil's anti-drug legislation, which dates from 2006 (Law 11.343/06). In the following section, special attention will be given to the available data regarding the growing adolescent mortality rate. The statistics discussed have been produced by official studies, and they are therefore recognized as representative of Brazilian reality. Finally, an attempt will be made to affirm and justify the possible relations between these ongoing parallel processes.

\section{VIOLENCE AND VIOLATION OF RIGHTS}

The beginning of the $21^{1 \text { st }}$ century had been characterized by an unequal distribution of economic, social and cultural assets, as well as discrimination, disregard for differences, uncertainty and violation of rights. These phenomena are neither inevitabilities nor detours of the adopted economical model - although they are often presented as such, they are in fact an element of the ongoing economical process where the development is regulated by the market (Rubio, 2009).

Although Brazilian society has its own characteristics, it is integrated to the contemporary global tendency regarding fragmentation of socio-cultural values and growing disregard for human rights. The economic and social model implemented in Brazil has produced human beings that are socially - and personally - overwhelmed, with difficult prospects of social mobility.

This contemporary social vulnerability has economic origins, but it is also characterized by lack of social belonging and perspectives, difficulty regarding access to information, and loss of self-esteem. The resulting situation of personal fragility influences the mental health of individuals and is therefore also related with the world of drug abuse and drug trafficking. Meanwhile, it is also responsible for establishing very restricted possibilities of social emancipation.

The described social hierarchy has, thus, a direct relation with the social model adopted, as well as with the shared belief in the project that justifies it and the conjecture it creates. As a result, the social subjects are valued according to their individual capacity to adhere to a homogeneous pattern, established historically and culturally (Gauer, 2005).

According to Jessé de Souza, the production and reproduction of marginalized social groups in Brazil are related to moral, cultural and political pre-conditions. Their situation of misery is not only economical, but also emotional, existential, and political, as it produces both individual and collective feelings of lack of social belonging, inferiority, and personal responsibility for life conditions (Souza, 2006). 
The starting point of this process is a basic and trans-classist consensus that, by means of invisible networks, disqualifies individuals and groups in precarious situations by characterizing them as "sub-producers" and "sub-citizens" (Souza, 2006). The permanent marginalization of certain social groups is related to the formation of a hidden evaluative hierarchy, allowed by the socio-economic circumstances, and built on the imposition of certain "pre-reflexive" beliefs, concealed behind a mask of would-be neutrality (Souza, 2006).

The Brazilian legal system, however, seems to exist in parallel with this bleak social reality. Brazil's Federal Constitution of 1988 recognized a large set of social rights destined to the Brazilian population in its entirety. These rights correspond to the values established by the social-democratic state model, and are referenced by the constitutional text in various moments, such as in the chapters that discipline education, health, and social assistance, among others.

Discussing this theme, Ingo Sarlet argues that fundamental rights are those guaranteed by the national law and juridical system that bear sufficient relevancy and essentiality (Sarlet, 2008). Fundamental rights are, therefore, human rights that have been recognized, by means of written inclusion, in the scope of constitutional law.

Nevertheless, even 20 years after the promulgation of the Federal Constitution of 1988, the reality experienced by Brazil's citizens is one of violation of human rights. This situation can be explained by the conditions of social vulnerability sustained by a significant part of the population, and by the fact that the system of public policies necessary to support the guarantees granted by the legal text has yet to be structured.

In this complex scenario, it is important to reflect on the role of the Law, as the legal system has proposed itself since 1988 to guarantee a different reality. Even though the different governments along the $20^{\text {th }}$ and $21^{\text {st }}$ century have implemented many social policies, these interventions have shared the characteristic of fractionizing social problems, viewing them as isolated facts. The consequence is that these policies have improved the population's life conditions in specific matters, such as access to decent alimentation, but have not been able to reduce the context of violence in which many children and adolescents are born and raised.

Equality is, thus, a difficult goal to be achieved, as the system is unequal both regarding material conditions and social belonging. Simultaneously, it is also hard to be different, in the sense of having personal subjectivity respected. Affirming differences is a daily challenge that individuals must face, as it is complicated to sustain personal specificities when confronted with the many prejudices that permeate society.

Joaquim Herrera Flores traces a counterpoint between the principles of equality and difference, concluding that the opposition to the idea of equality is not the 
concept of difference, but of inequality. The unequal social, cultural and economic conditions result in an unequal capacity to act between individuals, which consequently generates issues of social devaluation regarding groups considered different from the accepted patterns (Herrera, 2010). In this sense, the problems dealt with by individuals situated in these groups refer to their real, material needs, and not to abstract normative recognition.

Those who escape the dominating homogeneity become, at one time, visible and invisible. Visible because they denounce their reality, and, by extension, the system itself: their non-belonging and their social exclusion create an aggressive, symbolic visibility. On the other hand, their situation of vulnerability and violation of rights remains invisible. The result is a perverse visibility, where only the expression of the problem is acknowledged by the general population, while the social reality responsible for it is kept hidden (Sales, 2007).

Synthetically, there is visibility regarding the results, but the problem remains invisible. Consequently, the answers have been explicit actions - such as quick and superficial solutions in criminal policies and, at the same time, implicit ones such as the social segregation of these individuals.

Thus, the fight for a place in society and for the recognition of individuality integrates the routine of a majority of people. Additionally, while "being different" demands effort, "being equal", in the sense of being accepted as a person who deserves respect, is also incredibly difficult. Being recognized seems to be a necessity that evidences itself by means of confrontation with the impossibilities generated by contemporary human relations, created in a cultural context characterized by homogeneity, individualism and competitiveness. This is the issue faced both by individuals, and also by groups, characterizing a true battle for recognition, whose ambiance is set by diverse political and sociocultural contexts.

Using a metaphorical style, Homi Bhabha tells us that the desire to be recognized translates itself in a solicitation to be taken in to account. This is only possible in cultural interstices, in the boundaries between different worlds that indicate other possibilities of interaction, and in the recognition of identity not as something fixed, but in constant recreation (Bhabha, 2005). Recognizing others is, in this sense, a matter of guaranteeing the visibility of a different person's condition as a human individual, and therefore creating a possibility for personal identity. This ideal becomes concrete in the process of co-existing and interacting with differences in conditions of equality, and to a search for constant displacement and dialogue.

If the aggressive visibility results in questionable responses, the invisibilization of certain contexts and social realities makes identification with these persons, the basic condition for empathy and concern for their rights, impossible. The 
adopted system makes the alternative of identifying with the "the other" intangible, because of the prestige conceded to individualism, and the separation created by differences of class, gender, race or age. "The other" becomes devoid of his or her humanity, because social prejudices create a veil that covers their condition as a person.

Therefore, the proposed civilizing ideals are in contradiction with the material conditions of society. The promised equality has shown itself to be merely formal: its material realization continues to be inexistent, while the concept of equality itself seems to be in blatant disaccord with the installed system of values. The duality between invisibility and visibility is related to this strong disaccord between the modern ideal of "liberty and equality" and the contemporary conditions of social interaction.

From the perspective of children and adolescent's rights, modernity had its beginning some 200 years after French revolution, when these rights were affirmed by means of the International Convention on the Rights of the Child, in 1989 (Méndez, 1996). The problem is that this affirmation founded itself on the mentioned modern notion that we are all equals, even though, as discussed, this equality is merely formal.

Amidst these contradictions, the "Estatuto da Criança e do Adolescente - Lei 8069/90 - ECA" (Statute for Children and Adolescents Rights), celebrated its $26^{\text {th }}$ anniversary in 2016. Not long before its unanimous promulgation, the National Congress included articles 227 and 228 in the Federal Constitution, consolidating the adoption of the doctrinaire fundaments detailed in the International Convention on the Rights of the Child, ratified by Brazil in 1989. The "ECA" was meant to regulate the principles in the Federal Constitution, creating norms for the protection of children and adolescents' rights.

It must be said that this statute is a legislation of conceptual achievements, especially in what concerns the normative recognition of children and adolescents as subjects with rights. Also relevant is the conception of social equality contained in the legal text, which charges adults - society, state, and family - with the responsibility to guarantee to all these young subjects conditions of dignity that allow for the construction of their life projects.

Nevertheless, Brazilian data regarding children and adolescents' rights show that advances and setbacks have marked the time period between the promulgation of the statute and today. One remarkable achievement has been the reduction of child mortality: in 1990, 51,6 out of 1000 children born died before 1 year of age. In 2013, this cipher had been reduced to 12,9/1000 (UNICEF, OMS, World Bank, E UM, 2013). This reduction reflects an improvement on the quality of health and sanitation systems accessed by the poorer parts of the population.

Another advance has been the situation regarding childhood labor: in 1992, calculations estimated that 8.400 million 
children and adolescents in Brazil were working; in 2013, IBGE (Brazilian Institute of Geography and Statistics) registered a decrease of $56 \%$, with a total of 3.600 children and adolescents in laboring situations. Data also showed that there was an even greater reduction regarding children specifically, counterbalanced by a growth in adolescent employment, especially in rural areas.

This information is relevant because childhood labor is a topic that expresses the degree of material inequality in societies. According to data from OIT's 2015 Report, there are around 168 million children and adolescents around the world who work, and 70 million young individuals in indecent conditions of work. Indecent conditions of work reflect a low level of schooling; therefore, they are directly related to the time spent in school by the juvenile population. It is also important to register advances regarding the offer of places in elementary school, which now borders on universality. Unfortunately, the same level of success cannot be referred when it comes to rates of school permanence and access to high school education, factors that reflect on the social inequality pyramid.

However, in what concerns the involvement of young individuals with violence, there have been no significant advances. The application of social-educative measures, prescribed by "ECA" as responses to criminal acts committed by adolescents, is currently on a tendency of national rise. According to data from the Republican Presidency's Secretary of
Human Rights, the growth of the number of teenagers in closed-regime units is of about 1000 per year, with an estimation that, in 2012, there were 20.532 teenagers serving socio-educative measures in closed-regime units or in semi-liberty (Levantamento dos/as adolescentes em cumprimento de medida socioeducativa - 2012; Secretaria Nacional de Promoção dos Direitos da Criança e do Adolescente $^{2}$ ). This is not a direct indicator of growth in violence practiced by youths, but it confirms the existence of a culture of institutionalization that has been present in Brazilian public policies for children and teenagers since the beginning of the 20th century.

This historical tendency, described very accurately in the researches conducted by Irene Rizzini (Rizzini, 2011), is one that denounces abandonment by the state of its younger citizens, as well as of their right to live in society. Adolescence, together with infancy, is a phase of life that has been, and continues to be, poorly attended by Brazil's State policies. The inequality of opportunities, the lack of access to formal employment, the gaps between symbolic consumption and material consumption, the territorial segregation, the absence of public spaces destined for social and political participation, and the rises in informality are examples of the violence suffered by the generations currently going through their development phases in Brazil.

Estimate of adolescents serving socio-educative measures - 2012; National Secretariat for Promotion of Children and Adolescent's Rights. 
When researching about the reality of marginalized youths in Brazil, Simone de Assis reached some conclusions about the projects of life developed by these individuals: while teenagers in middle and upper classes have ambitious projects for their futures - sometimes even bordering on fantasy - teenagers in lower social strata tend to manifest aspirations restricted to their current life moment and to limit their expectations relatively to the social position they occupy since birth, revealing a high level of immediacy and of skepticism when thinking about the future (Assis, 1999).

Additionally, as a result of the State negligence to which the poorer social classes are subjected, young individuals in urban peripheries tend to accumulate a series of factors that serve as a base for the attribution of stereotypes and depreciations. Robert Castel comments (loose translation):

\begin{abstract}
Above all, the "youths from the peripheries" [...] accumulate a series of social counter-performances: failures in school, absence of professional future; people with common attributes that generally install themselves in precarious situations or use certain illegal options, such as informal economy, tracing, sometimes, a path to delinquency. (Castel, 2008, p. 10)
\end{abstract}

Still discussing the situation of young individuals, the author mentions that a common evocation of these adolescents is one of them as symbols of social inutility, because they are considered inca- pable of integrating themselves with the productive order, and also as symbols of dangerousness, because they are considered responsible for eventual rises in public insecurity (Castel, 2008).

In this stage, symbolic violence manifests itself. Pierre Bourdieu explains that, in the symbolic field, violence is expressed by means of distinct linguistic manifestations and cultural representations that society imposes to groups and individuals. It is a kind of violence that is invisible to its own victims, because it is exercised essentially by means of invisible, symbolic communication, and by the feelings it provokes (Bourdieu, 2003).

In the adolescents' case, the symbolic violence to which they are victims is directly related to the generalization of their identities and the patronization of their conducts. The stigmas imposed on teenagers from urban peripheries generate Manicheism, and consequently justify a lower credibility regarding adolescents from poorer social strata.

Two out of the infinite factors that compose the context of violence suffered by Brazil's youth are evidenced by this discussion: On one hand, the violence regarding the violation of fundamental rights; and on the other, the symbolic violence, permeated by social representations and depreciative stigmas associated to the condition of being a teenager, especially when associated to poverty. Facing theses contexts, the declared constitutional goal of providing youths with subsides for a dignified and autonomous 
development is only possible when a certain conception of State is adopted: that of a strong, responsible State, which is, therefore, capable of mobilizing its forces to reverse these trajectories of violence.

\section{THE WAR ON DRUGS AND THE ACCESS TO WEAPONS}

To begin with, it must be said that the problematic involving drug trafficking is not limited to juvenile criminality. In other words, drug trafficking is not a crime exceptionally reserved for adolescents or for young adults: According to data publicized by Brazil's Ministry of Justice in 2016 , regarding the year of $2015,25,5 \%$ of 607.731 overage individuals serving prison sentences in that year were doing so because of drug related charges.

Incarceration on account of drug trafficking had increased since the edition of the most recent Brazilian anti-drug legislation in 2006 (Law 11.343/2006), which amplified the interpretation of what can be considered traffic. This legal text supposedly decriminalizes the use of drugs but, at the same time, it allows for the inclusion of people found in possession of drugs in any quantity to be charged for drug trafficking. As a direct consequence, there is a growing incarceration of individuals for drug trafficking offenses.

Official ciphers from INFOPEN (2016), Brazil's center for information on the penitentiary system, refer that, in the last decade, Brazil's prison population saw an increase of $100 \%$. The problem is that, especially in the case of young adults, they answer to their charges while imprisoned, and receive sentences of about seven years, to be served at least $2 / 5$ in closed regime ( $2^{\text {nd }}$ article of Law n. 8072/90). This long time in prison generates acculturation, and fortification of criminal identity (Baratta, 2011).

Even though it proposes a few changes, this legislation follows the same political orientation as the formers concerning drug trafficking. According to Cristiano Maronna, Brazil's Drug Law represents "more of the same", reflecting an option for the prohibitionist model and its associated criminal policy of "war on drugs", already present in previous Brazilian legislations. The author highlights: "the trumpeted softening of the legal treatment destined to charges of possession for personal use is acts as a curtain of smoke to counter-balance the gravening of the penalization regarding drug trafficking" (Maronna, 2006, p. 2).

The 33rd article of Brazil's Drug Law reads as following (in loose translation):

Art. 33. To import, export, remit, prepare, produce, fabricate, acquire, sell, expose for sales, offer, have in storage, transport, carry, keep, prescribe, minister, deliver for consumption or provide drugs, even without financial earnings, without authorization or in disagreement with legal or regulatory determinations.

The numerous verbs present in this article reflect the infinite variety of conducts that can be embedded into it, allowing for criminalization 
of abstract actions and punitive arbitrariness. The result is that individuals integrating the high command of international traffic operations are often charged with the same crime as teenagers in urban peripheries that sell drugs as an economical alternative for fast earnings. The legislation fails to consider that these convicted adolescents are not the proprietors of the drugs apprehended, have no autonomy regarding the establishment of commerce networks, and do not obtain large profits from the sales they make.

Brazil's national drug policy follows a model inspired by the United $\mathrm{Na}$ tions convention, which is marked by a strong punitivism (Boiteux, 2014). Humanitarian treatment is prescribed to addicts, while drug traffickers are subjected to high prison sentences. However, there is a failure in providing clear distinction between these two figures, leading to widespread punishment of small drug retailers, and making technical criminal defense difficult on account of the vagueness of legal stipulations. For example, the normative text does not define what is a drug, or what precise quantities and attitudes characterize of the crime of trafficking, in opposition to drug use (Boiteux, 2014).

From a social perspective, drug trafficking moves the economy in the peripheries of large cities; it is seen as an activity fed by a promising consumer market, and one that propitiates subjective gains. For those victimized daily by permanent forms of symbolic violence, working in drug trafficking offers an experience of power, acceptance and visibility. Besides this, it also makes immediate consumption of economical assets possible, which allows individuals to boast an ascending social status. Additionally, in a phase of life where individuals search for identity - such as adolescence -, it provides a sentiment of belonging to a group (Athayde $\mathcal{E}$ Soares, 2005).

The urban peripheries are also victims to discriminatory police practices. Violence is used, and rights are neglected in one socio-cultural context to guarantee the wellbeing of another one, which includes the classes favored by the neoliberal State model (Wacquant, 2001). Since the beginning of the century, an amplification of State activities related to criminal prosecution has been observed. Meanwhile, measures regarding social protection do not grow in the same proportions. Loïc Wacquant contributes with the following reflection (loose translation):

The neoliberal criminal system presents the following paradox: it intends to remedy by means of "more state" in what concerns police and prisons and "less state" in what concerns economic and social contexts, which are the very cause of the generalized rise of objective and subjective insecurity in all the countries. (Wacquant, 2001, p. 7)

In the last decades, the number of people in prisons and, consequently, of those who depend on the prison industry, has gradually risen. Meanwhile, the number of individuals excluded from economic and social life has risen proportionally. 
Drug criminalization policies materialize in the form of an option of urban war against the populations of urban peripheries, provoking an aggravation of the conditions of life in these communities, which is ignored. In this sense, Juarez Cirino dos Santos infers that a criminal policy that focuses its attentions on delinquent individuals, and uses strategies of removal, segregation, healing and education, even if it does so using instruments of a humanized criminal law system, "does not cease to constitute the most acerbated form of repressive violence [...] (Santos, 1984).

Drug trafficking has also become a form of employment for teenagers in the peripheries or large cities. The International Labor Organization (ILO) recognizes drug trafficking as one of the worst forms of child labor in the world (Convention n. 182, ILO). Childhood labor, as it was formerly stated, expresses the inequalities found in the fields of social rights and opportunities. Additionally, the expression "the worst forms of labor" refers to those forms of labor considered dangerous for the healthy development of those in an important and peculiar stage of life. Working in drug traffic is a very real possibility for those who grow up in context of poverty and naturalized violence. In these conjectures, there is not even a clear distinction on whether the content of a conduct is licit or illicit, considering the culture in which the subject was socialized (Becker, 2008).

According to the latest studies, among adolescents serving socio-educative measures, $38,7 \%$ are involved in robbery and $27,5 \%$ in drug trafficking, while the percentages referring to other infractions are inexpressive (Levantamento dos/as adolescents em cumprimento de medida socioeducativa - 2012; Secretaria Nacional de Promoção dos Direitos da Criança e do Adolescente ${ }^{3}$.

While drug trafficking is not formally considered as a patrimonial crime, it is along with robbery, an infraction related to consumption: It propitiates immediate financial rewards, and therefore allows access to economical assets and social visibility. In parallel, drug trafficking and armed robbery are directly related to youth mortality. Teenagers become, thus, both authors and victims in the same context.

Even though drug trafficking is considered as a worrisome reality, this study has as its premise that what is truly considered grave is the social, cultural and emotional situation of Brazil's youth, which leads them to involvement in drug trafficking as an alternative to the lack of other future perspectives.

\section{YOUTH MORTALITY BY VIOLENT CAUSES}

The human rights for children and adolescents expressed in the International Convention on the Rights of the Child of 1989, have as their founding purpose the guarantee of dignified life conditions for children. They mean to distance the younger strata of the population from contexts

Estimate of adolescents serving socio-educative measures - 2012; National Secretariat for Promotion of Children and Adolescent's Rights 
of poverty, violence, war, mistreatment and sexual abuse, among other violations. It is expected of the adult population, and of the national governments, that they be capable of integrally protecting this social group.

Brazil is not a country where children and teenagers are born and raised among the military conflicts traditionally named as "states of war", nor are there frequent natural disasters in the national territory that generate international mobilization in favor of children, or a condition of economic misery. However, in Brazil, youths are dying in rising percentages, a tendency that becomes clear once the "Maps of Violence" - Mapas da Violência, in Portuguese - are analyzed.

The "Map of Violence" is an inter-institutional study (UNESCO, Organization of Ibero- American States for Education, Science and Culture, Ministry of Justice, Institute Sangari, e FLACSO/CEBELA), organized in a historical series, and based on official data from a period that spans between 1980 and 2014. It has the Brazilian Ministry of Health as a main source, and traces comparisons between the number of victims of death by fire weapon, age group of these victims, units of the federation, and cities where the deaths happened, as well as the race, color, and sex of the victims. Analysis of this data shows that the people most vulnerable to death by fire weapon in contemporary Brazil are young, black, masculine individuals who live in populous municipalities.
According to data from the Map of Violence 2015, an important issue is the ascending tendency of youth mortality by causes related to violence: the rate of violent deaths for adolescents between 16 and 17 years of age in 1980 was of $9,7 \%$, while in 2013 the same rate was of $46 \%$. The same source states that in 2012 , 3.627 young individuals in that age group were killed, followed by another 3.749 in 2013. This represents an average of 10,3 adolescents killed daily. Brazil is therefore ranked third country in the world in what concerns adolescent deaths by violent causes, with a rate of 54,9 adolescents killed out of every 100.000 in 2013, and still showing tendencies of growth.

Brazil is thus behind only Mexico and El Salvador, which have, respectively, rates of 95,5 and 55,8 deaths by violent causes out of every 100.000 youths, according to data collected in 2012. Brazil's rate is 275 times greater than those of countries like Austria, Japan, United Kingdom, and Belgium, which have rates of 0,2 homicides per 100.000 young individuals in the same age group (Waiselfsz, 2015²).

The Map of Violence for 2016 reports that between the years of 1980 and 2014, the number of people between 15 and 29 years of age victimized by homicides grew significantly more than the mortality of victims by fire weapon in other age groups: in 1980 there were 6.104 deaths by fire weapon, and in 2014, 42.291, showing a growth of $592,8 \%$.

\footnotetext{
Government study entitled "Map of Violence", published in 2015 .
} 
Complementarily, the study affirms that, according to IBGE (Brazilian Institute of Geography and Statistics) the age group of between 15 and 29 years of age represents $26 \%$ of the total Brazilian population, while the mortality for this age group represents $58 \%$ of the total population mortality (Waiselfsz, 20165). The teenagers and young adults who are killed tend to remain invisible to the eyes of national and international society, especially because their deaths are associated to their involvement with violence and drug trafficking.

The research coordinated by Jaqueline Sinhoretto, based on data from São Paulo's State Police's Ombudsman referring to the years of 2009 and 2011, reports that the victims of death due to police action in that state are predominately black (61\%) and male (97\%), also stating that $25 \%$ are from the age group comprehended between 15 and 19 years of age, $57 \%$ from the group of 15 to 24 years of age, and a total of $78 \%$ are younger than 29 years of age (Sinhoretto, 2014). Even if this research, carried out in the University of São Carlos, in São Paulo, cannot be extended as an indicator of national reality, since there is great inequality regarding forms of police action within Brazil, it is possible to affirm that besides the concentration of homicide victims in the group of young, urban, male Negros, the same profile is found on the data regarding homicides practiced by the police. Based on this finding, it can be said that these invisible deaths are also caused by the agents of the state them-

5 Government study entitled "Map of Violence", published in 2015. selves, being frequently justified by the media as a consequence of the victims' involvement with crime.

Statistic data alone is not enough to explain the conjecture. Reflections on the role of socio-juridical institutions when faced with these realities, provided by qualitative empirical studies, are equally important. Investigations developed by a UFRGS (Federal University of Rio Grande do Sul) research group on the topic ${ }^{6}$, the persistence of a punitivist mentality has been perceived amidst society and its institutions. The distance between these institutions and the adolescent's reality impacts their perception of the system's legitimacy to intervene. Otherwise, analysis of judicial decisions has evidenced the presence of arguments founded on the doctrine of irregular situation ${ }^{7}$, the scapegoating of the adolescents' families, and the subjectivity of socio-edu-

6 Research Group certified by CNPq (Brazil National Council for Research) - "A Efetividade dos Direitos Fundamentais dos Adolescentes Envolvidos em Situações de Violência" (EDAV).

7 The "Doctrine of Irregular Situation", or "Doutrina da Situação Irregular", in the original Portuguese, is the doctrine that oriented State treatment of children and adolescents in vulnerable social contexts in Latin America prior to the 1990's. This now obsolete doctrine based State intervention on the perceiving of a child or adolescents' situation as irregular regarding social parameters, allowing for young individuals to be removed from their families and communities and sent to institutions even if no crime had been committed. The justifications for this was the "superior interest of the minor", but, effectively, the practices endorsed by this doctrine resulted in an arbitrary and massive institutionalization of poor children and adolescents, while the social problems faced by these social groups remained ignored by public policies. 
cative execution, as well as reports of truculent approaches by institution officials and policemen (Costa \& Eilberg, 2015).

Public policies that strengthen vulnerable teenagers' life projects, allowing them to develop their subjective potentialities are the most effective way to counteract adolescents' involvement with violence and crime. Nevertheless, the social and political proposition represented by the "ECA" is currently disputed in Brazilian society, as it has been since the promulgation of the statute in 1990. The unanimous decision for its approval only happened due to a very specific political context, and has not been confirmed by institutional and political actions taken in these last 26 years.

This contradiction becomes evident when we consider that, nowadays, a proposition for an amendment to the Federal Constitution that would lower the minimum age for criminal responsibility is being analyzed in the National Senate, having already been approved by Congress.

\section{CONCLUSIONS}

An intimate relation can be traced between youth involvement with drug trafficking, spread throughout the peripheries of metropolitan centers in Brazil, and youth mortality in the same urban agglomerations.

Besides analyzing drug trafficking as a specific crime or socio-economical phenomenon, it must also be considered that the intervention of the Brazilian State in drug combat has had as a side effect the death of adolescents in alarming rates. The adopted model for drug combat also results in the mass incarceration of the younger and poorer portions of the population that live in urban peripheries and see drug traffic as a means to integrate market economy. However, these people, in their vast majority, have but a peripheral and subordinate participation in the drug trafficking network.

Faced with the evident growth in youth mortality caused by fire weapons, whether its authors are other adolescents involved in crime or policemen in action, it is possible to derive from the conjecture shown in this paper that the Brazilian State has been violating its juvenile population's human rights. This is a section of population that is frequently born and raised amidst violence, learns to naturalize death from a very young age, and has their life perspectives - or lack thereof - represented by drug traffic, prison, or death.

The alternative to this bleak context seems to be fully effectuating the rights of children and adolescents that were internationally recognized by the International Convention on the Rights of the Child, and adopted in Brazil's Federal Constitution. Thus, the country's social, ethical and political commitment must be structured based on the recognition of adolescents as subjects with rights, to whom the State needs to guarantee dignified life projects, in substitution of the tendency of death that has been observed. 


\section{REFERENCES}

Assis, S. (1999). Traçando Caminhos em uma Sociedade Violenta: a vida de jovens infratores e seus irmãos não infratores. Rio de Janeiro, Brazil: FIOCRUZ.

Athayde, C., Bill, M. V. E Soares, L. E. (2005). Cabeça de Porco. Rio de Janeiro, Brazil: Objetiva.

Baratta, A. (2011). Criminologia Crítica e Crítica ao Direito Penal. Rio de Janeiro, Brazil: Freitas Bastos.

Bhabha, H. K. (2005). O Local da Cultura. Belo Horizonte, Brazil: UFMG.

Becker, H. (2008). Outsiders: estudos da sociologia do desvio. Rio de Janeiro, Brazil: Zahar.

Boiteux, L. (2014). Drogas e Cárcere: Repressão às Drogas: aumento da população carcerária brasileira e alternativas. In S. S. Schecaira (Ed.), Drogas uma Perspectiva (pp. 83- 103). São Paulo, Brazil: IBCCRIM.

Bourdieu, P. (2003). A dominação masculina ( $3^{a}$ ed.). Rio de Janeiro, Brazil: Bertrand Brasil.

Castel, R. (2008). A Discriminação Negativa Cidadãos ou autóctones? [Francisco Morás, translator]. Petrópolis, Brazil: Vozes.

Costa, A. P. M., E Eilberg, D. D. (Ed). (2015). Justiça Juvenil na Contemporaneidade ( $1^{a}$ ed.). Porto Alegre, Brasil: DM.

Departamento Penitenciário Nacional INFOPEN (2016). Levantamento nacional de informações penitenciárias. Retrieved from http://depen.gov.br/DEPEN/noticias - 1/ noticias/infopen-levantamento-nacionalde-informacoes-penitenciarias-2016.

Gauer, R. M. C. (2005). Da Diferença Perigosa ao Perigo da Igualdade. Reflexões em torno do Paradoxo Moderno. Civitas - Revista de Ciências Sociais, 5(2).

Herrera Flores, J. (2010). La Construccíon De Las Garantias. Hasta Una Concepción
Antipatriarcal De La Liberdad Y La Igualdad. In F. Piovesan, D. Sarmento, \& D. Ikawa (Eds.). Igualdade, Diferença e Direitos Humanos. Rio de Janeiro: Lumen Juris.

Maronna, C. A. (octubre de 2006). Nova lei de drogas: retrocesso travestido de avanço. Boletim do IBCCrim número 167. Retrieved from https://www.ibccrim.org.br/boletim artigos/197-167-Outubro-2006

Méndez, E.G. (1996). Infância e Cidadania na América Latina. São Paulo, Brazil: Ed. HUCITEC.

Organização Internacional do Trabalho - OIT (2015). Relatório Medir o progresso na Luta contra o Trabalho Infantil.

Sales, M. A. (2007). (in)Visibilidade Perversa. Adolescentes infratores como metáfora da violência. São Paulo, Brazil: Cortez.

Santos, J. C. (1984). As Raízes do Crime. Rio de Janeiro, Brazil: Forense.

Sarlet, I. W. (2008). A eficácia dos Direitos Fundamentais. Porto Alegre, Brazil: Livraria do Advogado.

Secretaria Nacional de Promoção dos Direitos da Criança e do Adolescente do Brasil (2012). Levantamento dos/as adolescentes em cumprimento de medida socioeducativa. Brasília: Sinase.

Sinhoretto, J., Silvestre, G., \& Schlitter, M. C. (2014). Desigualdade Racial e Segurança Pública no Estado de São Paulo. Letalidade Policial e Prisóes em Flagrantes. São Carlos, Brazil: UFSCar.

Souza, J. (Org.). 2006. A Invisibilidade da Desigualdade Brasileira. Belo Horizonte, Brazil: UFMG.

Rizzini, I. (2011). O Século Perdido. Raízes Históricas das Políticas Públicas para a Infância no Brasil ( $3^{a}$ ed.). São Paulo, Brazil: Cortez.

Rubio, D. S. (2009). Sobre la racionalidad económica eficiente y sacrificial, la barbarie mercantil y la exclusión de los seres humanos concretos. Sistema Penal e Violência - Revista Eletrônica da faculdade de Direito, 1(1), 101-113. 
UNICEF, OMS, Banco Mundial, \& ONU (2013). Tendências e Níveis em Mortalidade Infantil, Relatório. New York: UNICEF.

Waiselfsz, J. J. (2015). Mapa da Violência. Juventude. Mortes matadas por Arma de Fogo no Brasil. Brasília, Brasil: Secretaria Geral da Presidência da República, Secretaria Nacional da Juventude y Secretaria da Igualdade Racial. Retrieved from https://www.mapadaviolencia.org.br/ pdf2015/mapaViolencia2015.pdf.
Waiselfsz, J. J. (2016). Mapa da Violência. Homicídios por Armas de Fogo no Brasil. Rio de Janeiro, Brazil: FLACSO/CEBELA. Retrieved from https://www.mapadaviolencia.org.br/ pdf2016/Mapa2016_armas_web.pdf.

Wacquant, L. (2001). As Prisões da Miséria. Rio de Janeiro, Brazil: Jorge Zahar Editor. 